\title{
Excretion of polyamines by children with Beckwith's syndrome
}

\author{
G B BARLOW
}

Department of Paediatric Surgery, Institute of Child Health, London

SUMMARY The urinary excretion of the polyamines-putrescine, spermidine, and spermine-was measured in 7 children with Beckwith's syndrome. Putrescine excretion was raised and spermidine excretion reduced. The raised putrescine and the low spermidine ratios were highly significant. These results are consistent with a disturbance in a metabolic pathway under growth hormone-like regulation.

The features of children with Beckwith's syndrome (sometimes known as EMG (exomphalos, macroglossia, gigantism) or Beckwith-Wiedemann syndrome) are macroglossia, somatic gigantism, visceromegaly, exomphalos, and a transient neonatal hypoglycaemia. ${ }^{1-2}$ The disorders in growth suggest that there is some disturbance of the control mechanism. However, in the only patient in whom growth hormone $(\mathrm{GH})$ production was studied, it was normal. ${ }^{3}$

GH facilitates the formation in the liver of the

Table 1 Clinical features of children with Beckwith's syndrome

\begin{tabular}{|c|c|c|c|}
\hline Case & $\begin{array}{l}\text { Age } \\
\text { (weeks) }\end{array}$ & $\begin{array}{l}\text { Weight } \\
(k g)\end{array}$ & \\
\hline 1 & 5 & $4 \cdot 5$ & $\begin{array}{l}\text { Umbilical hernia, large protruding } \\
\text { tongue, sloping forehead with } \\
\text { prominent occiput. } \\
\text { Blood glucose } 2.4 \mathrm{mmol} / \mathrm{l}\end{array}$ \\
\hline 2 & 1 & $3 \cdot 5$ & $\begin{array}{l}\text { Exomphalos, large protruding tongue, } \\
\text { abnormal ear lobes, hypoglycaemic } \\
\text { episodes }\end{array}$ \\
\hline 3 & 7 & $3 \cdot 45$ & $\begin{array}{l}\text { Exomphalos, enlarged tongue, perforation } \\
\text { of colon, malrotation of gastrointestinal } \\
\text { tract. } \\
\text { Blood glucose } 1.7 \mathrm{mmol} / 1\end{array}$ \\
\hline 4 & 1 day & $4 \cdot 7$ & $\begin{array}{l}\text { Exomphalos, enlarged protruding } \\
\text { tongue, large slanting forehead, } \\
\text { creases on ear lobes, large hands and } \\
\text { feet }\end{array}$ \\
\hline 5 & 1 day & $3 \cdot 3$ & $\begin{array}{l}\text { Exomphalos, glandular hypospadias, } \\
\text { enlarged left kidney }\end{array}$ \\
\hline 6 & 13 & $4 \cdot 95$ & $\begin{array}{l}\text { Small exomphalos, protruberant tongue. } \\
\text { Blood glucose } 1.0 \mathrm{mmol} / 1\end{array}$ \\
\hline 7 & 1 & $3 \cdot 1$ & $\begin{array}{l}\text { Exomphalos, enlarged protruding } \\
\text { tongue. } \\
\text { Blood glucose, } 1.8 \mathrm{mmol} / 1\end{array}$ \\
\hline
\end{tabular}

Conversion: SI to traditional units-glucose: $1 \mathrm{mmol} / 1 \approx 18 \mathrm{mg} / 100 \mathrm{ml}$

Department of Paediatric Surgery, Institute of Child Health G B BARLOW, senior lecturer in biochemistry polyamines-putrescine, spermidine, and spermine -by controlling the enzyme ornithine decarboxylase (EC 4.1.1.17). Cortisol also stimulates hepatic ornithine decarboxylase activity, both by itself and synergistically with $\mathrm{GH} .{ }^{4}$ If the abnormal intrauterine growth of children with Beckwith's syndrome were due to a fault in the GH-like regulating mechanism, changes might be expected in the excretion of polyamines. Although an increased excretion of total polyamines was reported in one patient with acromegaly in whom the enlargement of distal parts of the body was associated with prolonged excessive secretion of $\mathbf{G H}$, no further details were given. ${ }^{5}$ It is also stated that 'There are no known growth processes that occur without the prior stimulation of polyamine biosynthesis'. ${ }^{6}$ The urinary excretion of these polyamines was measured in a group of 7 children with this syndrome.

\section{Methods}

24-hour urine collections were made from a group of 10 children aged 2 months to 2 years who were not suffering infection or any growth disorder. These urine samples were used as controls. Similar collections were made from 7 children with Beckwith's syndrome (Table 1). Urine samples, without preservative, were stored deep-frozen $\left(-20^{\circ} \mathrm{C}\right)$ until required for analysis. Tissue samples were obtained at necropsy (controls), or at operation (Beckwith's syndrome), and these were also stored at $-20^{\circ} \mathrm{C}$ until required.

Aliquots of urine were hydrolysed in $6 \mathrm{~mol} / 1 \mathrm{HCl}$ at $100^{\circ} \mathrm{C}$ overnight. The free polyamines were measured using a modular automatic amino-acid analyser (ChemLab Instruments) with columns and buffers similar to those described by Marton et al. ${ }^{7}$ 


\section{Results}

When standards were added to urine samples and taken through the whole procedure, putrescine, spermidine, and spermine were recovered in yields of $88 \pm 6 \cdot 5 \%, 79 \pm 7 \cdot 2 \%$, and $83 \pm 4 \cdot 1 \%$ respectively (mean \pm coefficient of variation) (8 estimations). In the controls the 24-hourly urinary excretion of putrescine was $0.85 \pm 0.71 \mu \mathrm{mol} / \mathrm{kg}$ (mean \pm SD) (range 0.26-2.2) and spermidine $0 \cdot 45 \pm 0.36$ $\mu \mathrm{mol} / \mathrm{kg}$ (range $0 \cdot 02-1 \cdot 15$ ). Spermine was below the detection level $(\approx 0.05 \mu \mathrm{mol} / \mathrm{kg}$ per 24 hours $)$ in all but one child. When the age range was extended from 2 months to 8 years there were no significant differences for the excretion of putrescine and spermidine, but the amounts of both were found to be related to body weight $(r=0.72$ with $P<0.01$ and $r=0.65$ with $P<0.05$ ). These control values appear to be similar to those reported for adults. ${ }^{7}$

The urinary excretion of spermidine in children with Beckwith's syndrome was either very low or it was undetectable (detection limit $\approx 0.02 \mu \mathrm{mol} / \mathrm{kg}$ per 24 hours), the difference being significant $(P<0.05)($ Table 2). The excretion of putrescine was significantly increased $(P<0.05)$, while spermine could not be detected in any of the patients. The putrescine/spermidine ratio was very high in all but one patient.

In samples of tongue muscle removed at operation, the polyamine levels showed a reduced putrescine/

Table 2 24-hour urinary polyamine excretion ( $\mu \mathrm{mol} / \mathrm{kg})$ in children with Beckwith's syndrome

\begin{tabular}{llll}
\hline Case & Putrescine & Spermidine & Spermine \\
\hline 1 & $1.5^{*}$ & 0.1 & 0 \\
& $0.7^{*}$ & 0.1 & 0 \\
2 & $1.7^{*}$ & 0 & 0 \\
3 & 1.8 & 0 & 0 \\
4 & 1.0 & 0 & 0 \\
5 & 0 & 0 & 0 \\
6 & 2.0 & 0 & 0 \\
7 & 3.4 & 0 & 0 \\
\hline
\end{tabular}

*Analyses on 3 successive days.

Control levels: putrescine $0.85 \pm 0.71 \mu \mathrm{mol} / \mathrm{kg}$ per 24 hours (mean \pm SD), spermidine $0.45 \pm 0.36 \mu \mathrm{mol} / \mathrm{kg}$ per 24 hours (mean \pm SD), putrescine/spermidine ratio $3.0 \pm 3 \cdot 5$ (mean \pm SD). spermidine ratio compared with control specimens obtained at necropsy (Table 3 ).

\section{Discussion}

The stimulation of ornithine decarboxylase activity, on which polyamine formation depends, is controlled by $\mathrm{GH}$ in the kidney and liver, and by prolactin in the spleen. However, little appears to be known of the hormonal control in other tissues. ${ }^{8}$

The concentrations of polyamines in tissue appear to determine the rate of growth as in catch-up growth after a period of restricted food intake, ${ }^{9}$ and in liver regeneration after partial hepatectomy. ${ }^{10}$ The polyamines are believed to alter the rate of nucleic acid activity. Enhanced rates of ribonucleic acid and protein synthesis were observed after the rise in polyamine levels. ${ }^{11}$ The growth of tissue appears to be affected not only by the absolute amounts of polyamine present but also by the ratios of the different components. Thus in various tumours changes take place in the spermidine and putrescine ratios. $^{7}$

It is possible therefore, that the growth disorders in Beckwith's syndrome are associated with the high putrescine excretion and low spermidine and putrescine ratios in the urine. The raised output of putrescine and the reduced output of spermidine may have been due to a reduced conversion of putrescine to spermidine in the patients, or to enhanced metabolism of the spermidine. While in infancy children with Beckwith's syndrome grow faster than normal, they tend to slow down to normal rates later. During this stage it is desirable to recheck the urinary polyamine levels which may conceivably be close to the normal range. If these results can be shown to be typical in this syndrome, then they raise the possibility of a better understanding of the mechanisms of a wider series of growth disorders.

I thank Professor A W Wilkinson and $\mathrm{Mr} \mathrm{J}$ A S Dickson for allowing me to study their patients, and Dr P A McAnulty for estimating the tissue polyamine levels.

Table 3 Tissue levels of polyamines (mmol/kg wet tissue) in children with Beckwith's syndrome

\begin{tabular}{|c|c|c|c|c|c|}
\hline Group & Tongue & $\begin{array}{l}\text { Age } \\
\text { (months) }\end{array}$ & Putrescine & Spermidine & Spermine \\
\hline $\begin{array}{l}\text { Control }(n=3) \\
\text { Patients with Beckwith's } \\
\text { syndrome }(n=2)\end{array}$ & $\begin{array}{l}\text { Necropsy specimen } \\
\text { Necropsy specimen } \\
\text { Necropsy specimen } \\
\text { At operation } \\
\text { At operation }\end{array}$ & $\begin{array}{l}3 \frac{1}{2} \\
4 \text { hours } \\
11 \text { years } \\
14 \\
11\end{array}$ & $\begin{array}{l}190 \\
460 \\
320 \\
260 \\
340\end{array}$ & $\begin{array}{r}60 \\
100 \\
100 \\
120 \\
180\end{array}$ & $\begin{array}{l}160 \\
200 \\
190 \\
210 \\
230\end{array}$ \\
\hline
\end{tabular}

Putrescine/spermidine ratio in controls 3.7, putrescine/spermidine ratio in children with Beckwith's syndrome $2 \cdot 0$. 


\section{References}

1 Irving I M. The EMG syndrome: exomphalos, macroglossia, gigantism. Prog Pediatr Surg 1970; 1: 1-61.

2 McKusick A. Mendelian inheritance in man. 4th ed. Baltimore: Johns Hopkins University Press, 1974: 413.

3 Wiedemann H R, Spranger J, Mogharei M, et al. UUber das Syndrom Exompahlos-Makroglossie-Gigantismus, über generalisierte Muskelhypertrophic, progressive Lipodystrophie und Miescher-Syndrom im Sinne diencaphaler Syndrom. Eur J Pediatr 1968; 102: 1-36.

4 Richman R A, Underwood L E, VanWyck J J, Voina S J. Synergistic effect of cortisol and growth hormone on hepatic ornithine decarboxylase activity. Proc Soc Exp Biol Med 1971; 138: 880-4.

5 Lipton A, Sheehan L M, Kessler G F, Jr. Urinary polyamine levels in human cancer. Cancer 1975; 35: 464-8.

- Russell D H. Polyamines in normal and neoplastic growth. New York: Raven Press, 1973: 4.

7 Marton L J, Russell D H, Levy C C. The measurement of putrescine, spermidine, and spermine in physiological fluids by use of an amino acid analyser. Clin Chem 1973; 19: 923-6.

8 Richards J F. Ornithine decarboxylase activity in prolactin-treated rats. Biochem Biophys Res Commun 1975; 63: 292-9.

9 McAnulty P A, Williams J P G. Polyamines and their biosynthetic decarboxylases in various tissues of the young rat during recovery from undernutrition. Biochem $J$ 1977; 162: 109-21.

10 Fausto N. The control of ornithine decarboxylase activity during liver regeneration. Biochim Biophys Acta 1971; 238: 116-28.

11 Raina A, Jänne J. Polyamines and the accumulation of RNA in mammalian systems. Fed Proc 1970; 29 : 1568-74.

Correspondence to Dr G B Barlow, Institute of Child Health, Department of Paediatric Surgery, 30 Guilford Street, London WC1N 1EH.

Received 15 February 1979 